malnourished-looking baby, who has been affected in the last few weeks of pregnancy only, and the short relatively well-proportioned baby with rubella syndrome whose growth was retarded in the first trimester. The long thin baby has a relatively normal number of thin cells whereas the rubella baby has a low cell population in organs throughout his body. These two situations are not, however, mutually exclusive so that a baby whose growth has been retarded for months rather than weeks may present some reduction in cell population in addition to a reduced cell size. In any individual case the infant's potential for physical and mental development is likely to be limited by the extent to which the cell population of different organs has been permanently depleted.

\title{
REFERENCES
}

Anderson, J. M., Milner, R. D. G. \& Strich, S. J. (1966), Lancet ii, 372.

Butler, N. R. (1965). In Gestational Age, Size and Maturity. Clin. Develop. Med. no. 19, p. 74. [M. J. R. Dawkins and W. G. MacGregor, editors.] London.

Butler, W. H. \& Wigglesworth, J. S. (1966). Br. F. exp. Path. 47, 242.

Dawkins M. J. R. (I964). Proc. R. Soc. Med. 57, ro63.

Eckstein P., Mckeown, T. \& Record, R. G. (1955). \%. Endocr. 12, 108.

Gruenwald, P. (1963). Biologia Neonat. 5, 215.

Hammond, J. (r96r). Ciba Fdn Symp.: Somatic Stability in the Nervly Born, p. 5. [G. E. W. Wolstenholme and M. O'Connor, editors.] London: Churchill.

McBurney, R. D. (1947). West. 7. Surg. Obstet. Gynec. 55, 363 .

McKeown, T. \& Record, R. G. (I953). F. Endocr. 9, $4 \mathrm{I} 8$.

McLaren, A. \& Michic, D. (1960). Nature, Lond, 187, 363.

Naeye, R. L. (1965a). Archs Path. 79, 284.

Naeye, R. L. (1965b). Am. \%. Path. 47, 905.

Robertson, W. B., Brosens, I. \& Dixon, H. G. (1967). 7. Path. Bact. 93, 58 I.

Robinson, R. J. \& Tizard, J. P. M. (I966). Br. med. Bull. 22, 49.

Schiff, D. (I968). PhD. Thesis, University of London.

Scott, K. E. \& Usher, R. (1964). New. Engl. F. Med. 270, 822.

Shelley, II. J. (1964). Br. med. F. i, 273.

Wigglesworth, J. S. (1964). Э. Path. Bact. 88, г.

Wigglesworth, J. S. (1968). In Aspects of Praematurity and Dysmaturity, Nutricia Symposium, p. I 19. [J. H. P. Jonxis, H. K. A. Visser and J. A. Troelstra, editors.] Leiden: H. E. Stenfert Kroese N.V.

Winick, M. \& Noblc, A. (I966). F. Nutr. 89, 300.

\section{The transmission of immune globulins from the mother to the foetal and newborn young}

\section{By F. W. Rogers Brambell, ARC Unit of Embryology, Department of Zoology, University College of North Wales, Bangor}

The young mammal or the young bird is equipped with a battery of antibodies derived from its mother that provide it with an effective but temporary immunity to disease, before it has learned to produce its own. At birth or hatching it has entered a world where it is beset with infections, from an environment where it was remarkably free from these and where, in consequence, it had little or no opportunity of developing specific resistance, even if its lymphoid system had reached a stage of 
development sufficient to render this possible. Accordingly, the transmission of passive immunity provides it with a ready-made set of antibodies to those antigens to which its mother has been exposed and to which there is therefore a probability of her young being exposed. These antibodies are immune serum globulins, with molecular weights of about 160000 , or else polymers of up to five such units. That they are transmitted, with their biological activity intact, from the maternal circulation to that of the young across the intervening tissues, including either the foetal membranes, or the mammary gland and neonatal gut, or else both, has important bearings on the subject of this conference. First, knowledge of the route and method by which intact protein molecules are transmitted to the circulation of the young is as necessary to understanding its nutrition as is knowledge of the passage of diffusible substances. Secondly, passive immunity is an essential requirement of the young, even though the immune globulin involved is quantitatively a minor component. Thirdly, study of the transmission of immunity has thrown some light on the transmission of other proteins, such as albumin and transferrin, and suggests that further research might extend the list.

The transmission of passive immunity from mother to young may occur before birth, or after birth, or at both these times. Human infants and the young of monkeys, rabbits and guinea-pigs are born with a full equipment of passive immunity. The concentration of maternal antibodies in the circulation of the young animal at birth may equal, or even exceed, that in the circulation of the mother. Although the young animal grows quickly, with a corresponding increase in blood volume and consequent dilution of the maternal antibody concentration, there is little, if any, augmentation of the passive immunity by way of the milk after birth. The maternal antibodies have been transmitted to the young of these specics while they are still in the uterus, across the foetal membranes which envelop the foetus and constitute the maternal/foetal barrier. However, the structures that are involved in transmission in rabbits and guinea-pigs are not developed in primates, in which transmission must be by another route.

The young of cattle, goats, sheep, horses, donkeys and pigs are born with little or no passive immunity and they derive their complement of maternal antibodies from the colostrum during their first few hours of independent life. Maternal antibodies secreted in the colostrum and ingested with the first feed are transmitted rapidly to the circulation of the newborn animal across the intestinal wall. This capacity of the young animal to absorb the antibodies intact from the gut contents is transitory, lasting only a few hours. Subsequently the antibodies will be digested instead of being transmitted to the circulation intact. The newborn calf, for example, depends for its passive immunity on being fed with the antibody-rich colostrum within a few hours of birth, and to deprive it of this is to rob it of much of its powers to resist infection. The antibodies are at such a high concentration in the colostrum and are transmitted so rapidly from the first feed to the circulation of the calf that within a few hours of birth they attain a concentration in its blood that equals or exceeds that of the mother.

Rats, mice, hedgehogs (Morris, 1960 , 1961 ), dogs and cats form an intermediate 
group, between these two, in that passive immunity is transmitted in them from mother to young both before and after birth. Although in these animals a significant amount is transmitted across the foetal membranes to the foetal circulation before birth, the greater part is transmitted after birth by way of the milk. The postnatal transmission is not limited to a few hours after birth but continues for a long period and may even extend throughout the greater part of lactation. Transmission ultimately terminates abruptly in rats and mice through the gut becoming impermeable to antibodies although these are still present in quantity in the milk which the young animal is receiving (Halliday, 1955a, 1959).

Birds, no less than mammals, depend for survival from infections on the transmission of passive immunity from the mother. In them maternal circulating antibodies are secreted into the egg with the yolk materials while it is still in the ovary. These antibodies persist in the yolk throughout incubation and are gradually absorbed and transmitted to the circulation during the last few days before hatching and the first few days after hatching (Buxton, I952; Brierley \& Hemmings, I956). During embryonic development the yolk becomes surrounded by and contained in the yolk-sac, which is morphologically an extension of the mid-gut, with a very vascular wall lined with an endodermal epithelium. It is connected to the gut by a stalk in which the yolk-sac arteries and veins run but through which the yolk cannot pass. Shortly before hatching the yolk-sac, with its residue of yolk, is retracted into the body of the chick through the umbilicus. The endodermal epithelial cells lining the yolk-sac absorb the antibodies from the yolk and transmit them to the circulation both before and after hatching until the yolk-sac is reduced to a rudiment at 4 or 5 days of age.

Transmission of immunity before birth in rabbits, guinea-pigs, rats and mice is also by way of the yolk-sac. In all these animals the yolk-sac is a large structure, enveloping more than half the surface of the conceptus and persisting throughout gestation. Its wall is vascular and it is connected to the foetus by the yolk-sac stalk in which the vitelline vessels run. Its surface is covered by endoderm but, unlike that of the chick, it is an incomplete sac, lacking a lower side; consequently the endoderm of the upper side is freely exposed in the uterine lumen. It has been shown experimentally that transmission of immunity in these animals takes place by secretion of maternal circulating antibodies into the uterine lumen and their absorption from there by the endodermal cells of the yolk-sac which transmit them by way of the vitelline circulation (Brambell, Hemmings, Henderson, Parry \& Rowlands, I949). Thus it is not by way of the chorio-allantoic placenta and the allantoic vessels that transmission occurs in these animals but by a route that corresponds morphologically to that in the bird. In all these the maternal/foetal barrier which must be traversed is the yolk-sac epithelium of endoderm cells. Transmission after birth, in all those species in which it occurs, obviously is by way of the gut and takes place mainly, perhaps exclusively, in the ileum; thus in these also it is an endodermal epithelium which must be traversed. We do not know the route of transmission before birth in hedgehogs, dogs or cats and experimental evidence is necessary to determine whether it occurs by way of the endoderm of the yolk-sac or foetal 
gut or by way of the chorio-allantoic placenta. In the primates, however, the rudimentary nature of the yolk-sac precludes that route and such experimental evidence as is available indicates that it takes place almost certainly by way of the chorioallantoic placenta and not by way of the foetal gut. Thus the primates appear to be a clear exception to what might otherwise be a general rule of transmission by an endodermal epithelium.

The rabbit and the rat have proved particularly convenient for the experimental investigation of the transmission of immunity before and after birth respectively. Since transmission in the rabbit takes place by absorption of serum proteins from the uterine lumen by the exposed endoderm of the yolk-sac, it is easy to inject solutions of antibodies or isotopically labelled proteins into the lumen of the gravid uterus and to follow their passage from there to the foetal circulation. The young rat is an even more convenient experimental object for it continues to transmit $\gamma$-globulins from the gut to the circulation until it is 18 days of age. Consequently in vivo experiments can be performed by the simple expedient of administering the protein solution by stomach tube. Recently suitable techniques have been developed in my laboratory for studying transmission in vitro by the inverted intestinal sac method (Bamford, I966) or by intestinal rings (unpublished).

When immune rabbit serum is injected into the uterine lumen of a 24 -day pregnant rabbit and the foetal serum is harvested after $24 \mathrm{~h}$ the antibody titre averages one-sixteenth of that of the immune serum injected. The growth increment of a foetal rabbit at this age is $28 \%$ over $24 \mathrm{~h}$ (Huggett \& Widdas, 195 I). Since the $\gamma$ globulin concentration in the immune rabbit serum was $c$. II $\cdot 3 \mathrm{mg} / \mathrm{ml}$ and that of the foetal serum $c .2 \cdot \mathrm{I} \mathrm{mg} / \mathrm{ml}$ the proportion of maternal $\gamma$-globulin in the foetal serum at the end of the experiment was: $\frac{1}{16} \times \frac{11 \cdot 3}{2 \cdot 1} \times 100=34 \%$. Therefore the amount of antibody $\gamma$-globulin transmitted to the circulation from the single dose administered was more than sufficient to provide for the normal growth increment over $24 \mathrm{~h}$ (Brambell, Hemmings, Henderson, \& Kekwick 1953). Since the serum volume of a 25 -day rabbit foetus is not very different from the I $\mathrm{ml}$ of immune serum that was administered it is evident that only about one-sixteenth of the antibody in the dose was transmitted unaltered to the circulation and that the remaining fifteen-sixteenths has not been accounted for. Using isotopically labelled $\gamma$-globulin it can be shown that most of this is degraded by the cells of the foetal yolksac. Thus, only $12 \%$ of homologous $\gamma$-globulin that is available to the yolk-sac endoderm is transmitted intact to the foetal circulation and the greater part is degraded (Hemmings, 1956).

The young of immune mother rats are born with a serum titre of about onesixteenth of that of the mother. During the first 3 days after birth, provided they are suckled by the mother, the titre in their serum rises to near equality with hers and remains at this level until $\mathrm{I} 8$ days of age (Halliday, $1955^{b}$ ). Therefore they must continue to receive throughout this period sufficient antibody to provide for the growth increment as well as for replacement of loss by catabolism. By oral administration of immune serum or labelled $\gamma$-globulin it can be shown that the capacity to transmit these to the circulation declines sharply at 18 days of age and is lost by 
20 days of age (Halliday, 1955a). Antibody appears in the circulation very rapidly after oral administration of immune serum to a 12 -day-old rat; it can be detected within 30 min and attains a maximum after $3 \mathrm{~h}$. After a single oral dose of immune rat serum at 12 days of age, the amount of antibody appearing in the circulation is directly proportional to the volume of the dose up to $0.1 \mathrm{ml}$ but it does not increase with larger doses (Halliday, 1957). The amount transmitted from a dose of $0.1 \mathrm{ml}$ or more is such as to produce a concentration in the serum of approximately $\frac{1}{32}$ of that in the serum administered. Twelve-day-old rats are growing in weight at $8.25 \%$ per day hence the amount absorbed from the single dose is sufficient to account for the growth increment of $\gamma$-globulin over a period of approximately $9 \mathrm{~h}$. Since they normally suckle at more frequent intervals it is apparent that the whole of their $\gamma$-globulin could be of maternal origin up to 18 days of age at least. Assuming a plasma volume of $\mathrm{I} \cdot \mathrm{ml}$ at most, at $\mathrm{I} 2$ days of age approximately onethird of the $\gamma$-globulin in a dose of $0.1 \mathrm{ml}$ of serum would need to be transmitted to produce a relative concentration of $\frac{1}{32}$ in the circulation. Therefore about twothirds of the $\gamma$-globulin in the dose is degraded in the gut. Transmission therefore appears to be rather more efficient than in the yolk-sac of the foetal rabbit. However, in young ruminants, during the brief period after birth when transmission occurs, most of the $\gamma$-globulin is transmitted intact, though there is evidence of some degradation in the lumen of the gut.

Transmission is a selective process for $\gamma$-globulins are transmitted preferentially to other serum proteins and some $\gamma$-globulin fractions may be transmitted more readily than others. Further, $\gamma$-globulins from different species are transmitted at different rates. In the rabbit the rates of transmission of antitoxins prepared in a variety of species have been compared very precisely by administering mixtures of serum containing two or more antitoxins prepared in different species against different toxins. This enabled comparison of the rates of transmission of each, simultaneously, by the same yolk-sac. The rates varied by two orders (Batty, Brambell, IIemmings \& Oakley, 1954). Transmission is known to be selective in the rabbit, rat, mouse, guinea-pig, hedgehog, man, and fowl but it is not known to be selective in the ruminants although in the pig $\gamma \mathrm{M}$-globulin is not transmitted.

It has been shown that the part of the $\gamma$-globulin molecule responsible for transmission is in the $\mathrm{Fc}$ fragment or C-terminal half of the heavy chain. The $\mathrm{Fc}$ fragment is transmitted in the rabbit and mouse whereas the Fab fragment is scarcely transmitted at all in the rabbit (Brambell, Hemmings, Oakley \& Porter, 1960; Morris, $\left.196_{3}\right)$.

In rats and mice, but not so far as is known in rabbits, the $\gamma$-globulins of some species interfere with the transmission of others (Morris, 1957; Halliday, 1957). The Fc fragments, but not the Fab fragments, also interfere with the transmission of other $\gamma$-globulins. The amount of interference produced by a $\gamma$-globulin is quantitatively related both to the rate at which it is itself transmitted and to the extent to which its transmission can be interfered with by other $\gamma$-globulins (Morris, I 964).

The selective transmission of $\gamma$-globulins suggested that transmission might involve attachment to specific receptors on, or in, the cells, the rate of attachment 
or release from which was characteristic of each species of $\gamma$-globulin molecule. Interference is very difficult to account for on any other hypothesis than competition for specific receptors, and so powerfully reinforces the evidence for these. Clearly, on this assumption, attachment to the receptors must be by a region of the heavy chains included in the Fc fragment.

All the membranes through which transmission occurs are provided with brush borders of microvilli, and pinocytosis can be demonstrated between the bases of these villi. This is true of the endoderm of the yolk-sac of the foetal rabbit (Luse, I958) and of the intestine of the young rat (Clark, I959). Colloidal materials injected into the uterine cavity of the pregnant rabbit are absorbed pinocytotically and are demonstrable in vacuoles in the cells. The endodermal cells of the jejunum and ileum of the young rat up to 18 days of age exhibit very active pinocytosis and the apices of the cells are crammed with vesicles. Colloidal materials administered by mouth are ingested by the cells and can be demonstrated in these apical vesicles. The laden vesicles move down deeper into the cells and discharge their contents into a very large vesicle which occupies much of the space between the nucleus and the apical part of the cell. These vesicles are rich in enzymes and display the characteristics of phagolysosomes (Vacek, 1964; Jeal, 1965; Shervey, 1966). It seems reasonable to suppose that digestion is taking place in them. Pinocytosis appears to come to an abrupt end or at lcast to be reduced to a very low level after i 8 days of age, at the same time as the transmission of immunity stops. Since no other signs of the cellular uptake of colloidal materials can be discerned with the electron microscope and since pinocytosis is co-extensive in time with transmission of immunity it is reasonable to conclude that the $\gamma$-globulin is ingested in the pinocytotic vesicles and that much of it is degraded by the lysosomal enzymes in these but that some is protected from enzyme action and secreted by the cells into the intercellular spaces, from where it would drain into the lymphatic channels. We suggest, therefore, that attachment to the specific receptors which we have postulated provides this protection from degradation and ensures transmission, and that the receptors are situated on the surface of the cell membrane that is invaginated to form the phagosomes. All the protein molecules that fail to attach to receptors, and hence are unprotected, would then be degraded. Pinocytosis and enzymic digestion in phagolysosomes are accepted phenomena and receptors have been invoked to account for many cellular processes. The only element of this hypothesis that is novel is the assumption that receptors in the walls of the phagosomes can protect protein molecules attached to them from degradation (Brambell, 1966).

Much of the evidence concerning transmission of immunity is consistent with this hypothesis. Although in the primates transmission appears to take place through the chorio-allantoic placenta which must involve transport by the trophoblast, instead of the endoderm as in other species, it is known to be selective; for example, $\gamma \mathrm{M}$ - and $\gamma \mathrm{A}$-globulins are not transmitted whereas $\gamma \mathrm{G}$-globulin is transmitted in the human. Moreover, the syncytium of the human chorionic villi have a brush border of microvilli and the peripheral syncytioplasm near full term is full of vacuoles and channels that appear to result from pinocytosis (Boyd, Hamilton \& Boyd, 
1968). The appearance under the electronmicroscope thus is very reminiscent of that of the rat intestinal epithelium during transmission. Modification of the hypothesis is necessary to account for the apparently non-selective nature of transmission in the neonatal ruminant. Transmission is confined to such a brief period and is so intense in these animals that receptors, if present at all, must be assumed to play a negligible part in the process as degradation within the phagosomes is probably minimal.

How does all this bear on the problem of the nutrition of the foetus and the newly born? I would attempt to answer this question by asking two others. How many other substances of large molecular size are transmitted from mother to young by the same route as $\gamma$-globulins? How much of its nutrition depends on the intracellular degradation of foodstuffs absorbed by pinocytosis? Although it is not possible at present to give a satisfactory answer to either of these questions we do know enough to be confident that the answers are likely to be illuminating.

\section{REFERENCES}

Bamford, D. R. (1966). Proc. R. Soc. B r66, 30.

Batty, I., Brambell, F. W. R., Hemmings, W. A. \& Oakley, C. L. (1954). Proc. R. Soc. B r42, 452. Boyd, J. D., Hamilton, W. J. \& Boyd, C. A. R. (1968). J. Anat. ro2, 553.

Brambell, F. W. R. (I966). Lancet ii, 1087.

Brambell, F. W. R., Hemmings, W. A., Henderson, M. \& Kekwick, R. A. (1953). Proc. R. Soc. B I4I, 300 .

Brambell, F. W. R., Hemmings, W. A., Henderson, M., Parry, H. J. \& Rowlands, W. T. (1949). Proc. R. $S o c \mathrm{~B} 136,131$.

Brambell, F. W. R., Hemmings, W. A., Oakley, C. I. \& Porter, R. R. (1960). Proc. R. Soc. B I51, 478.

Brierley, J. \& Hemmings, W. A. (1956). J. Embryol. exp. Morph. 4, 34 .

Buxton, A. (1952). F. gen. Microbiol. 7, 268.

Clark, S. L. (1959). F. biophys. biochem. Cytol. 5, $4 \mathrm{I}$.

Halliday, R. (1955a). Proc. R. Soc. B r43, 408.

Halliday, R. (1955b). Proc. R. Soc. B r44, 427 .

Halliday, R. (1957). Proc. R. Soc. B 148, 92.

Halliday, R. (1959). F. Endoct. 18, 56 .

Hemmings, W. A. (1956). Proc. R. Soc. B 145, 186.

Huggett, A. St G. \& Widdas, W. F. (1951). F. Physiol., Lond. 114, 306.

Jeal, F. $(1965)$. Thesis, University of Wales.

Luse, S. A. (1958). Transactions of the Fourth Conference on Gestation, p. I15-I41. New York: Josiah Macy Foundation.

Morris, B. (1960). Proc. $R$. Soc. B $\mathbf{5 5 2}_{\mathbf{5}}, 137$.

Morris, B. (Ig6r). Proc. R. Soc. B r54, 369.

Morris, I. G. (1957). Proc. R. Soc. B 148, 84 .

Morris, I. G. (1963). Proc. R. Soc. B 157, 160.

Morris, I. G. (1964). Proc. R. Soc. B 160, 276.

Shervey, P. (1966). Anat. Rec. I54, 422.

Vacek, Z. (1964). Csl. Morfol. 12, 292. 